\title{
PERFIL E TUTORIA
}

\author{
MENTORING MEDICAL EDUCATION
}

Dalmo de Souza Amorim¹, Maria Lúcia Borges Gattás²

\begin{abstract}
1Docente Aposentado. Departamento de Clínica Médica da Faculdade de Medicina de Ribeirão Preto - USP. ${ }^{2}$ Doutora na Área de concentração de Enfermagem Psiquiátrica da Escola de Enfermagem de Ribeirão Preto - USP. CorResPondência: Rua Bernardino de Campos, 1236 Apto 132. CEP 14015-130. Ribeirão Preto - SP. Fone (fax) (16) 36364992. e-mail:dalmosamorim@uol.com.bremalubor@uol.com.br
\end{abstract}

As Resoluções que cuidam das Diretrizes Curriculares Nacionais para os cursos universitários da área da saúde, aí incluído o curso médico, falam da construção de perfil acadêmico e profissional. Essas diretrizes contêm dizeres de perfil, imprecisos, aqueles no âmbito de genéricos princípios universais. As novas diretrizes foram vistas como correspondendo a um novo discurso de modernidade. A tal respeito interroga-se sobre o que o novo diz e quer dizer, no contexto do pensamento de Foucault ${ }^{1}$.

O conceito pedagógico de perfil é relativamente novo e está atrelado a outros elementos, representados pelo domínio das competências e habilidades. Perrenoud ${ }^{2}$ define competência como sendo a capacidade de agir eficazmente, em um determinado tipo de situação, apoiada em conhecimentos, mas sem limitar-se a eles. As competências não são, em si, conhecimentos: elas utilizam, integram ou mobilizam tais conhecimentos.

Esta introdução sinaliza a dificuldade da apresentação do tópico. Mais do que uma aspiração, o perfil deve ser o elemento central do processo pedagógico. Dessa forma, o seu alcance está subordinado aos elementos de hereditariedade e do meio ambiente: ele carece ser moldado com os recursos existentes. Dito de outra maneira: o perfil, para ser alcançado, requer meios compatíveis com o ideal desejado. É claro que, apesar das identidades encontradas nos elementos de hereditariedade e do meio ambiente, o perfil é marcado pela tipicidade.

Esta digressão encontra eco no texto elaborado por Barbosa ${ }^{3}$. Entende ela por perfil o conjunto de conhecimentos e de habilidades necessárias ao desenvolvimento da pessoa e à qualificação profissional, construindo em cada um a postura e as atitudes desejadas no exercício de suas futuras atividades. Para Elsie Barbosa, concepção de um curso - e cada componente curricular, - deve ser bem clara e justificada pelo perfil final a ser alcançado. Esse perfil deve ser perseguido no desenvolvimento da proposta do curso delineado de modo diverso para os alunos. Assim, os diferentes conteúdos deverão possibilitar que todos caminhem para o mesmo ponto de chegada: com criatividade, autonomia de pensamento, segurança nas decisões e nas suas escolhas.

\section{Instrumentos para o atingimento do perfil}

A pedagogia do perfil devolve o projeto humanístico da Educação à sua verdadeira trajetória, preocupando-se em atingir aquele objetivo como excêntrico e não como egocêntrico. Mas cabe observar que a pedagogia do perfil não é método: se assim fosse, ela conteria modos comuns de proceder - os mesmos em todos os cursos - de como fazer a distribuição dos conhecimentos, de como ensinar saberes já sabidos e de como fazer a avaliação coletiva através de exames que testam a memorização do conhecimento. Ao contrário, essa prática - pedagogia do perfil - requer que todo aluno, no âmbito do projeto pedagógico de seu curso, seja conduzido de acordo com a fundamentação de sistema tutorial; isso tem em conta as aspirações e as habilidades de cada aluno para o ajuste de suas próprias necessidades para o atingimento do perfil delineado pelo projeto pedagógico do curso. 
É absolutamente necessário compreender que o perfil final não é uma aspiração de verificação tardia. Ele carece de um modo contínuo de avaliação de desempenho: ele se desdobra em perfis intermediários, com relações interpessoais fundamentadas na prática do sistema tutorial de estudos. O modo tem na sua base, o princípio da interdisciplinaridade. Uma grande exigência é a mudança comportamental dos professores: eles precisam aprender em equipe, mudando o padrão de interação entre eles e os alunos em cada etapa do desenvolvimento dos estudos.

Em experiência vívida, Manço ${ }^{4}$ deu excelente contribuição ao assunto. As suas experiências eram mais do que discursivas, pois tinham lastro em uma situação concreta de adoção da pedagogia do perfil em projeto pedagógico do então recém-criado curso médico.

Usando técnicas de análise qualitativa de dados - com base em informações obtidas através de questionários, - aquele autor examinou o papel da tutoria na formação do aluno com vistas ao perfil desejado. $\mathrm{O}$ aspecto principal não era discutir os aspectos conceituais da tutoria, mas extrair das respostas a eventual transformação do aluno $(\mathrm{n}=32)$, as qualidades do tutor $(n=4)$ e a avaliação e a promoção dos alunos de um mesmo período (quarto período) de um novo curso (médico) que adotou a pedagogia do perfil como referencial e a tutoria como instrumental. Com as ressalvas necessárias à técnica adotada nas condições do estudo, bem como ao modo de apresentação das respostas de uns e outros, a conclusão desse autor é a de contribuição pouco importante, quando muito acessória, da tutoria na formação do perfil.

É necessário dar ênfase, no entanto, ao fato de que os dois grupos - alunos e tutores - não tinham vivência educacional dessa natureza. Ambos - tutores e alunos - emergem de processo ensino-aprendizagem convencional, massificado, de alcance de sucesso (imediato e fugaz) de ações pedagógicas nãotransformadoras.

Todas as matrizes curriculares e seus modos as tecnologias educacionais - devem ser admitidos como tendo função definida: o atendimento do perfil delineado para o aluno. A função é mais importante do que a discussão nominal ou da instrumentalização dessas práticas

Dentro do que aqui se discute - recursos instrumentais em educação - divulga-se que o aprendizado, baseado em problemas (PBL), torna os alunos elementos ativos, independentes e responsáveis por seu próprio aprendizado, sendo eles capazes de aplicar, em situações práticas, o conhecimento que lhes foi transmitido. Essa abordagem eliminaria defeitos do sistema tradicional que valoriza a memorização de fatos, que torna o aluno um recipiente passivo de informações.

Essa abordagem merece exame racional e desapaixonado. Perrenoud ${ }^{2}$ ocupa-se de uma dessas análises do ensino denominada por ele situação-problema. Seus comentários estão centrados nas exigências feitas ao professor, além da falta de sinergia entre o material didático disponível e o exigido nessas circunstâncias. O professor não pode utilizar os atuais meios de ensino, concebido em outras perspectivas. Não se pode esperar que o professor imagine e crie sozinho, ininterruptamente, situação-problema, cada uma mais apaixonante e pertinente do que as outras (indispensável falar da relevância do regime de trabalho do pessoal docente, eis que o preparo do material didático per se absorverá praticamente todo o tempo do professor).

As estratégias instrucionais - aí incluídas as novas tecnologias educacionais - são apenas instrumentos para alcance do objetivo definido; o perfil. Elas chegam ao núcleo de professores que demonstrem interesse em oferecer ensino integrado - cognitivo, atitudinal etc. - para a autonomia do aluno, o que deve estar implícito no perfil desejado.

A metáfora da árvore ${ }^{5}$ - da construção das matrizes curriculares - é a de um esquema arborescente com raízes na biologia, na filosofia, na psicologia etc., em um tronco que se eleva e se divide em ramos e pequenos galhos; as disciplinas. As resoluções que cuidam das diretrizes curriculares - tendo em conta as tecnologias educacionais - poderão ligálas em harmoniosa determinação interdisciplinar.

Funcionalmente, eles avançam para um modelo em rede, interdisciplinar, com múltiplas conexões descentralizadas. Por isso, na construção de modelos que visem o atingimento de perfil, as tecnologias educacionais - aprendidas e apreendidas pelos professores - concorrem para que as disciplinas sem relações hierarquizadas deixem de ter um ponto fixo. A falta de referência fixa talvez explique o medo com que, com freqüência, não se tente a construção de projeto interdisciplinar.

Para nós, a implementação dessas estratégias instrucionais será notável e indispensável no sentido 
da construção de projeto interdisciplinar para o atingimento do perfil enunciado nas resoluções que cuidam das estruturas curriculares nacionais, embora não havendo nelas ineludível consistência explicativa dos rumos desejados. Cabe destaque para a colaboração de Gattás ${ }^{6}$; além de discutir os principais conceitos ligados à interdisciplinaridade, lança luz sobre uma questão essencial; não se avança nessa direção sem outra mudança paradigmática. Essa última, ainda mais fundamental, é a de contar com pessoas com mentes abertas, dispostas a desconstruir seus conceitos, abrir mão de alguns de seus próprios paradigmas, ouvir os demais e trabalhar articuladamente.

\section{REFERÊNCIAS}

1 - Foucault M. O nascimento da clínica. 5a.ed. Rio de Janeiro: Forense Universitária; 2001.

2 - Perrenoud P. Construir as competências desde a escola. Porto Alegre: Artmed; 1999.

3 - Barbosa E. Os perfis na concepção e estruturação de projeto pedagógico de cada curso. In: Amorim DS. Evolução de projeto pedagógico: estudo de caso - Medicina. Área estratégica da saúde. Uberaba: Universidade de Uberaba; 2003.

4 - Manço JC. Perfil e tutoria: avaliação de uma experiência. In: Amorim DS. Evolução de projeto pedagógico: estudo de casoMedicina. Área estratégica da saúde. Uberaba: Universidade de Uberaba; 2003.

5 - Amorim DS. As implicações do avanço científico-tecnológico na definição do perfil do médico. Medicina (Ribeirão Preto) $1989 ; 22: 144-9$.

6 - Gattás MLB. Interdisciplinaridade: formação e ação na área de saúde. Ribeirão Preto: Holos Editora; 2006. 